ISSN 1557-4989

(C) 2007 Science Publications

\title{
Maize Oil Can Replace Fish Oil in The Diet of Grouper Postlarvae (Epinephelus Coioides) Without Adversely Affecting Growth or Fatty Acid Composition
}

\author{
${ }^{1}$ Jin Niu, Yong-Jian Liu, ${ }^{1}$ Li-Xia Tian, ${ }^{2}$ Kang-Sen Mai, ${ }^{3}$ Qi-Cun Zhou, ${ }^{1}$ Hui-Jun Yang and ${ }^{1}$ Chao-Xia Ye \\ ${ }^{1}$ Nutrition Laboratory, Institute of Aquatic Economic Animals, School of Life Science, Sun Yat-sen \\ University, Guangzhou 510275, P.R. China \\ ${ }^{2}$ Laboratory of Aquaculture Nutrition, College of Fisheries, Ocean University of China, \\ Qingdao 266003,P.R. China \\ ${ }^{3}$ Laboratory of Aquatic Animal Nutrition and Feed, College of Fisheries, Ocean University of Zhanjiang, \\ Zhanjiang 524025, P.R. China
}

\begin{abstract}
This experiment was conducted to evaluate the effects of dietary lipid sources on growth, survival and body composition of 40 day post hatch larval grouper, Epinephelus coioides. Fish were fed fish meal and protein hydrolysate based diets for 32 days with either $100 \%$ maize oil or $100 \%$ fish oil in triplicate from 40-day after hatching to slaughter size (fish weight: $0.32 \mathrm{~g}$ to $11 \mathrm{~g}$ ). Final body wet weight (FBW: $11.8 \pm 0.7$ and 11.1 \pm 0.1 , respectively), weight gain (WG: $3556 \pm 251$ and $3360 \pm 189$, respectively), specific growth rate (SGR: $11.2 \pm 0.2$ and $11.1 \pm 0.2$, respectively) and survival rate ( $80 \pm 5$ and $79 \pm 4$, respectively) were not significantly affected by dietary lipid sources $(P>0.05)$. The effect of different oil sources on the composition of tissues was significant only for dorsal muscle lipid. In dorsal muscle, lipid content was significantly higher in fish oil group. The fatty acids composition of the muscle lipids well reflected the fatty acids composition of the experimental diets. The growth performance showed that a balance is required between growth-promoting essential fatty acids (EFA) qualities of dietary n-3 highly unsaturated fatty acid (n-3 HUFA) and their potentially growthinhibiting (pro-oxidant) qualities. Results indicated when EFA of the diet are sufficient for the development of postlarvae, there is no difference whether use fish or maize oil in the formulated diets, 2.87\% n-3 HUFA is sufficient for grouper postlarvae development and more n-3 HUFA are not necessarily beneficial to fish performance.
\end{abstract}

Key words: Grouper (Epinephelus coioides), lipid source, growth, fatty acid

\section{INTRODUCTION}

Lipid nutrition are important for fish growth because they are source of energy, essential fatty acids (EFA) and other lipid classes like phospholipids, sterols and fat-soluble vitamins. Several studies have shown that the source and content of the lipid of the feed have a major impact on larval development ${ }^{[1]}$. Most marine fish require n-3 HUFA (such as docosahexaenoic acid (22:6n-3, DHA) and eicosapentaenoic acid (20:5n-3, EPA)) for normal growth and development ${ }^{[2]}$. Fish oil is the only commercially available source of EPA and DHA ${ }^{[3]}$, and it is widely used in the formulation of commercial aquaculture feeds. These fatty acids, function as critical structural and physiological components of the cell membranes of most tissues ${ }^{[4]}$. Fish oil contains the long chain n-3 HUFA and thus it is considered to have superior quality than maize oil ${ }^{[5]}$. However, global fisheries are now stagnating and the current yield of fish oil from industrial fisheries, circa
1.4 million tons in 1996 , is unlikely to be significantly exceeded in future ${ }^{[6]}$. Fish farming consumed a total of 560,000 tons of fish oil in $1996^{[6]}$. Global aquaculture has grown at $11.6 \%$ per annum compound growth since $1984^{[7]}$ and is continuing to grow at a similar rate. It is clear that demand for fish oil from aquaculture must, before long, exceed supply. This problem will be exacerbated by growing environmental pressure to decrease exploitation pressure on finite marine resources and by increasing consumer perception that levels of pollutants such as dioxin in fish oils have now reached unacceptable levels ${ }^{[8]}$. Moreover, it has been estimated that aquaculture feeds currently use about $60 \%$ of the global supply of fish oil, and by the year 2010 , fish oil used in aquaculture will be about $75 \%$ of the world supply ${ }^{[9]}$. For these reasons, finding alternatives to fish oils in farmed aquaculture feeds is becoming an increasingly urgent issue. The use of alternate lipids in aquaculture needs to be addressed not only to possibly reduce diet cost, but also to potentially

Corresponding Author: $\quad$ Prof. Yong-Jian Liu, Institute of Aquatic Economic Animals, School of Life Science, Sun Yat-sen University, No 135 Xin'gang Xi Road, Guangzhou P.R. China, 510275. Tel: +86 208411 0789; fax: +862084115896 
reduce the current pressure on fisheries resources. On the other hand, many aquaculturist and nutritionists are interested in lipid nutrition of fish, such as lipid source, because this dietary component has great effect on growth and heath of the organism ${ }^{[10]}$, as well as on the quality of resulting products ${ }^{[11]}$.

The effects of different lipid sources of dietary on different fish species have been demonstrated: Oncorhynchus mykiss [12], Sciaenops ocellatus [13], Salvelinus fontinalis ${ }^{[14]}$, Anguilla australis ${ }^{[15]}$. Fish oil replacement with unconventional lipid sources seems to be possible if the essential fatty acid (EFA) requirements are satisfied $[16,17,18]$. But to date, the works on grouper are relatively limited. The nutrient requirement studies of grouper (Epinephelus coioides) have been addressed on calcium and phosphorus ${ }^{[19]}$, Lmethionine ${ }^{[20]}$, tryptophan ${ }^{[21]}$ and replacement of fish meal by animal by-product meals ${ }^{[22]}$. No research has been reported the effect of dietary lipid sources on grouper postlarvae (Epinephelus coioides).

Consequently, this study was conducted to determine the influence of dietary source of oil on growth, survival and body composition of grouper postlarvae, Epinephelus coioides.

\section{MATERIALS AND METHODS}

Experimental diets and diet preparation: Two isonitrogenous $(59 \%$ protein) and isolipidic (16\% lipids) diets were formulated (Table 1). The two lipid sources were fish oil and maize oil and they were from New Zealand (Bakels Edible Oils Ltd., Mt Macnganui). Diet preparation was as described by previous study ${ }^{[23]}$. Briefly, all dry ingredients for each of the experimental diets were weighed, combined and thoroughly mixed until homogenous in a Hobart-type mixer, and then distilled water $(20 \%, \mathrm{v} / \mathrm{w})$ and oils were added and thoroughly mixed. Pellets were obtained using a pelletizer (Institute of Chemical Engineering, South China University of Technology, Guangzhou, PR China), air-dried to about $100 \mathrm{~g} \mathrm{~kg}^{-1}$ moisture and ground using a mortar and pestle and graded via a series of different-sized metal sieves. Diets must be prepared as microparticles whose sizes must be adapted to the size of the postlarvae mouth. Size of the microparticulate diets used in the experiment was 300 um for grouper postlarvae at the initial feeding period, then 500 to 800 um from day 1 to $6,1.0$ to $1.2 \mathrm{~mm}$ from day 7 to $12,1.5 \mathrm{~mm}$ from day 13 to 18 and 1.5 to 2.5 $\mathrm{mm}$ to day 32. Diets were sealed in vacumm-packed plastic bags and stored in $-20^{\circ} \mathrm{C}$ until feeding. The available dietary energy was calculated using physiological fuel value of $4.0,4.0$ and $9.0 \mathrm{kcal} \mathrm{g}^{-1}$ for protein, carbohydrate and lipid, respectively ${ }^{[24]}$.
Table 1: Ingredients and proximate composition of the experimental diets (g per $100 \mathrm{~g}$ dry matter)

\begin{tabular}{|c|c|c|}
\hline Ingredients & Maize oil & Fish oil \\
\hline White fish meal $^{\mathrm{a}}$ & 51.8 & 51.8 \\
\hline Fish protein hydrolysate ${ }^{b}$ & 20 & 20 \\
\hline Soybean lecithin $^{c}$ & 5 & 5 \\
\hline Fish oil $^{\mathrm{d}}$ & / & 8 \\
\hline Maize oil $^{\mathrm{d}}$ & 8 & / \\
\hline $\mathrm{a}-\operatorname{Starch}^{\mathrm{e}}$ & 5 & 5 \\
\hline Vitamin premix ${ }^{\mathrm{f}}$ & 1.6 & 1.6 \\
\hline Mineral premix ${ }^{\mathrm{g}}$ & 4 & 4 \\
\hline Methionine $^{\mathrm{h}}$ & 1 & 1 \\
\hline Tryptophan ${ }^{\mathrm{h}}$ & 0.5 & 0.5 \\
\hline Vitamin $C^{c}$ & 0.5 & 0.5 \\
\hline Others $^{1}$ & 2.6 & 2.6 \\
\hline \multicolumn{3}{|l|}{ Composition (\%) } \\
\hline Moisture & 16.1 & 15.9 \\
\hline Crude protein & 59.0 & 59.1 \\
\hline Crude lipid & 16.0 & 16.2 \\
\hline Ash & 9 & 9 \\
\hline n-3 HUFA & 2.87 & 6.12 \\
\hline Crude energy (Kcal/100g) & 400 & 402.2 \\
\hline
\end{tabular}

${ }^{\mathrm{a}}$ Imported from New Zealand.

${ }^{\mathrm{b}}$ Huaqi Guangzhou Company Ltd, Guangzhou, China.

${ }^{\mathrm{c}}$ Jiakangyuan Beijing Company Ltd, Beijing, China.

d Imported from New Zealand (Bakels Edible Oils Ltd., Mt Macnganui).

${ }^{\mathrm{e}}$ Guangzhou Chengyi Company Ltd, Guangzhou, China.

fper $\mathrm{kg}$ vitamin mix: retinyl acetate $2.5 \mathrm{~g}$; cholecalciferol $6.25 \mathrm{~g}$; all-rac-a-tocopheryl acetate $75 \mathrm{~g}$; menadione $2.5 \mathrm{~g}$; vthiamin $0.25 \mathrm{~g}$; riboflavin $1 \mathrm{~g}$; Dcalcium pantothenate5 g; Pyridoxine HCL $0.75 \mathrm{~g}$; Cyanocobalamin $2.5 \mathrm{~g}$; Niacin $2.5 \mathrm{~g}$; Folic acid $0.25 \mathrm{~g}$; Biotine $2.5 \mathrm{~g}$; Meso-inositol $75 \mathrm{~g}$; meso-inositol $324 \mathrm{~g}$ cellulose $500 \mathrm{~g}$.

${ }^{\mathrm{g}}$ per kg mineral mix: KCL $90 \mathrm{~g}$; KI $40 \mathrm{mg}$; $\mathrm{CaHPO}_{4}{ }^{-}$ $2 \mathrm{H}_{2} \mathrm{O} 500 \mathrm{~g}$; $\mathrm{NaCL} 40 \mathrm{~g}$; $\mathrm{CuSO}_{4}-5 \mathrm{H}_{2} \mathrm{O} 3 \mathrm{~g} ; \mathrm{ZnSO}_{4}$ $7 \mathrm{H}_{2} \mathrm{O} 4 \mathrm{~g} ; \mathrm{CoSO}_{4}-7 \mathrm{H}_{2} \mathrm{O} 20 \mathrm{mg} ; \mathrm{FeSO}_{4}-7 \mathrm{H}_{2} \mathrm{O} 20 \mathrm{~g}$; $\mathrm{MnSO}_{4}-\mathrm{H}_{2} \mathrm{O} 3 \mathrm{~g} ; \mathrm{CaCO}_{3} 215 \mathrm{~g} ; \mathrm{MgSO}_{4}-7 \mathrm{H}_{2} \mathrm{O} 124 \mathrm{~g}$; Cellulose $0.94 \mathrm{~g}$.

${ }^{\mathrm{h}}$ Supplied as L-form; Shanghai Cangda Amino acid Company Ltd, Shanghai, China.

${ }^{\mathrm{i}}$ Others $(\mathrm{g} / 100 \mathrm{~g})$ : lycine $1 \mathrm{~g}$; Choline chloride $1.6 \mathrm{~g}$.

Fish culture: The system consisted of six aquaria (150 $\mathrm{L} \times 70 \mathrm{~W} \times 60 \mathrm{H} \mathrm{cm})$, each supplied with 5001 continuously filtered seawater circulating all the time. Each aquarium was connected with a separate recirculating system, and could modulate the flow rate of water based on the fish developmental condition. Each recirculating system was equipped with a sand filter and packed-column biological filter. During the trial, the diurnal cycle was $12-\mathrm{h}$ light/12-h dark. Water 
quality parameters were recorded daily. During the feeding trial, water quality parameters were maintained as follows: salinity, $30 \mathrm{mg} \mathrm{L}^{-1}$; temperature, $28 \pm 0.3^{\circ} \mathrm{C}$; dissolved oxygen, $5.7 \pm 0.1 \mathrm{mg} \mathrm{l}^{-}$; ammonia-nitrogen, $0.077 \pm 0.006 \mathrm{mg} \mathrm{l}^{-}$. When the condition of the fish was stable, the water was exchanged according to the water quality. The 40 day post hatch grouper were obtained from Evergreen (Zhanjiang) South Ocean Science and Tech. Co., Ltd. They were acclimated to the experimental conditions and fed the basal diet (without oil supplementation and other ingredients are the same) for 5 days before the experiment started. Fish of similar size were selected, and groups of all fish were weighed before being stocked into individual tanks. Three replicate tanks (with 80 fish initially in each tank) were used for each dietary treatment. All fish from each tank were weighed as a group at the end of the feeding trial. Initial and final weights were calculated by dividing the group weight by the number of fish. During the trial, fish were fed the experimental diets five times daily $(7: 30,10: 00,15: 00,18: 00,21: 00)$ to satiation. Survival was calculated by individual counting of all the surviving fish at the beginning and the end of the experiments. During the experiment, each tank was noted the amount of feed intake to calculate feed conversion ratio (FCR).

Sampling and dissection: After the final weighing and fasting for $24 \mathrm{~h}$, twelve fish per tank were randomly collected and used for analysis of body composition and dorsal muscle fatty acids composition. Fish were randomly captured and killed by immediate spinal destroying for measure and dissection. Wet weight (WW) of the intact fish and corresponding organs was determined and the hepatosomatic index (HSI $=100 \times$ liver $\mathrm{WW} /$ fish $\mathrm{WW}$ ), viscerosomatic index (VSI $=100 \times$ viscera $\mathrm{WW} /$ fish $\mathrm{WW}$ ) were calculated. Livers and dorsal muscle dissected were frozen immediately in liquid nitrogen and stored at $-70 \square$ until in need.

Analytical methods: Diets and dissected tissues were analyzed in triplicate for proximate composition. Moisture, crude protein, crude lipid and ash were determined using standard methods ${ }^{[25]}$. Moisture was determined by drying in an oven at $105^{\circ} \mathrm{C}$ for $24 \mathrm{~h}$. Crude protein $(\mathrm{N} \times 6.25)$ was analyzed by the Kjeldahl method after acid digestion (1030-Auto-analyzer, Tecator, Sweden); Crude ash by incineration in a muffle furnace at $550^{\circ} \mathrm{C}$ for $24 \mathrm{~h}$. Crude lipid was determined by the ether-extraction method by Soxtec System HT (Soxtec System HT6, Tecator, Sweden);

Total lipid of dorsal muscle was extracted according to previous method ${ }^{[26]}$. Fatty acids from lipid samples were methylated using $10 \%$ potassium hydroxide in methanol for $1 \mathrm{~h}$ at room temperature ${ }^{[27]}$. Fatty acid methyl esters were then analysed and quantified using a Hewlett-Packard HP-5890 gas chromatograph (Hewlett-Packard, Avondale, PA, USA) in a cross-linked $5 \%$ phenylmethyl silicone gum phase column (length $25 \mathrm{~m}$; internal diameter $0.32 \mathrm{~mm}$; film thickness $0.25 \mathrm{~mm} ; \mathrm{N}_{2}$ as the carrier gas; HP-Ultra 2), equipped with flame ionisation detection. The injector and detector temperatures were 280 and $300^{\circ} \mathrm{C}$, respectively. The column temperature set at $190^{\circ} \mathrm{C}$ was then increased to $260^{\circ} \mathrm{C}\left(2^{\circ} \mathrm{C} / \mathrm{min}\right)$ and held for $5 \mathrm{~min}$. Results are expressed as the percentage of each fatty acid with respect to total fatty acids.

Statistical analyses: Statistical analysis of the result was done by Student t-test using the software of the SPSS for Windows (ver10.0, U.S.A.).

\section{RESULTS}

There were no significant differences among dietary groups for feed conversion ratio (FCR), WG, SGR, survival and FBW (Table 2). There were also no significant differences in HSI and VSI between treatments (Table 2). In the present study, FCR was probably overestimated because feed waste for the first six days can not be determined accounts.

No significant differences were found between treatments for whole body or liver compositions (Table 3).No difference in dorsal muscle moisture and protein contents were found. However, fish fed fish oil had significantly higher lipid content in dorsal muscle than fish fed maize oil $(P<0.05)$.

The fatty acids content of the experimental diets and dorsal muscle are shown in Table 4. The FA composition of dorsal muscle well reflected the fatty acids composition of the experimental diets, as levels of SAT, MONO, n-3 HUFA and n-6 HUFA all reflected the composition of each respective dietary lipid. Fish fed the diet containing maize oil had the highest levels of MONO, and fish fed the fish oil diet had the highest levels of n-3 HUFA.

Table 2: Effect of diet on growth performance, tissue indices and feed conversion ratio of the fish.

\begin{tabular}{|c|c|c|}
\hline $\begin{array}{l}\text { Treatment } \\
\text { Performance }\end{array}$ & Maize oil & Fish oil \\
\hline $\mathrm{IBW}^{\mathrm{a}}(\mathrm{g})$ & $0.32 \pm 0.02$ & $0.32 \pm 0.01$ \\
\hline $\mathrm{FBW}^{\mathrm{b}}(\mathrm{g})$ & $11.8 \pm 0.7$ & $11.1 \pm 0.1$ \\
\hline$W^{c}(\%)$ & $3556 \pm 251$ & $3360 \pm 189$ \\
\hline SGR $^{d}$ & $11.2 \pm 0.2$ & $11.1 \pm 0.2$ \\
\hline Survival (\%) & $80.2 \pm 5.1$ & $78.8 \pm 4.3$ \\
\hline $\mathrm{FCR}^{\mathrm{e}}$ & $1.27 \pm 0.09$ & $1.34 \pm 0.04$ \\
\hline $\mathrm{HSI}^{\mathrm{t}}$ & $4.23 \pm 0.21$ & $4.19 \pm 0.12$ \\
\hline $\mathrm{VSI}^{\mathrm{g}}$ & $12.4 \pm 0.2$ & $12.6 \pm 0.1$ \\
\hline
\end{tabular}

Data represent mean \pm S.E.M. $(n=3)$.

Values in the same row with different letters are significantly different $(P<0.05)$.

${ }^{\mathrm{a}} \mathrm{IBW}$ : Initial body wet weight $(\mathrm{g})$.

${ }^{\mathrm{b}}$ FBW: Final body wet weight $(\mathrm{g})$.

${ }^{\mathrm{c}} \mathrm{WG}(\%)$ : weight gain $=100 \times($ final body weight- initial body weight) / initial body weight $(\mathrm{g})$.

${ }^{\mathrm{d}}$ SGR: special growth ratio $=100 \times($ ln final wt.- $\ln$ initial wt.) /32 days. 
${ }^{\mathrm{e}}$ FCR: feed conversion ratio $=100 \times$ dry feed $(\mathrm{g}) /$ weight gain $(\mathrm{g})$.

${ }_{\mathrm{f}}^{\mathrm{f}}$ HSI: hepatosomatic index $=100 \times$ liver $\mathrm{WW}(\mathrm{g}) / \mathrm{fish}$ WW $(\mathrm{g})$

${ }^{\mathrm{g}}$ VSI: viscerasomatic index $=100 \times$ viscera WW $(\mathrm{g}) / \mathrm{fish}$ WW

Table 3: Influence of maize oil diet and fish oil diet on whole body, dorsal muscle and liver composition (\%) in larval grouper.

\begin{tabular}{cll}
\hline Composition & maize oil & fish oil \\
\hline Whole body & & \\
Moisture & $70.12 \pm 0.14$ & $69.65 \pm 0.13$ \\
Protein & $16.09 \pm 0.08$ & $16.17 \pm 0.20$ \\
Lipid & $8.95 \pm 0.13$ & $8.95 \pm 0.06$ \\
Ash & $3.84 \pm 0.05$ & $3.88 \pm 0.01$ \\
Dorsal muscle & & \\
Moisture & $77.23 \pm 0.14$ & $77.70 \pm 0.51$ \\
Protein & $18.07 \pm 0.05$ & $17.81 \pm 0.24$ \\
Lipid & $2.40 \pm 0.05^{\mathrm{b}}$ & $2.70 \pm 0.08^{\mathrm{a}}$ \\
Liver & & \\
Moisture & $59.25 \pm 0.94$ & $57.29 \pm 0.34$ \\
Protein & $8.32 \pm 0.58$ & $7.34 \pm 0.27$ \\
Lipid & $12.92 \pm 1.03$ & $13.62 \pm 0.87$ \\
\hline
\end{tabular}

Data represent mean \pm S.E.M. $(\mathrm{n}=3)$.

Values in the same row with different letters are significantly different $(P<0.05)$.

\section{DISCUSSION}

Most marine fish require the EFA (n-3 HUFA) for normal reproduction and growth. These essential FA have two main functions in fish the same as in vertebrate: to maintain the structural and functional integrality of the cell membranes of most tissues and act as the precursor of eicosanoids ${ }^{[28]}$. Recent investigations have indicated that DHA is necessary for development for the nervous system including brain and retina in larvae and juvenile. Marine fish larvae lack $\Delta^{5}$ desaturase rending them unable to synthesize DHA and EPA from linolenic acid $(18: 3 n-3){ }^{[29]}$. Thus most marine fish require pre-formed highly unsaturated long chain fatty acids (EPA; DHA) in their diets ${ }^{[3]}$. Fish oil offers a range of fatty acid classes, mainly contains the long chain n-3 HUFA and thus was considered more superior than maize oil in fish feed ${ }^{[5]}$. Experiments conducted using live prey ${ }^{[30,31]}$ or a compound diet ${ }^{[32]}$ have shown that the optimal level of n-3 HUFA in diet for marine fish larvae is around 3\% (dry matter). The present experiment was designed to have $2.87 \%$ and $6.12 \%$ (dry matter) n-3 HUFA in the maize oil diet and fish oil diet respectively, when fish were fed fish meal and protein hydrolysate based diets for 32 days, the fish oil did not improve the fish performance (WG, SGR and survival). The use of maize oil in diet of grouper resulted in substantial growth and excellent feed efficiency. Grouper seem able to efficiently utilize maize oil as the dietary lipid source as long as their requirement for EFA is met. The result indicated that n-3 HUFA content in the maize oil diet is sufficient for postlarvae development, the other more n-3 HUFA provided by fish oil is unnecessary. The conclusion of our present experiment that superabundant n-3 HUFA are not necessarily beneficial to fish performance is similar with previous study ${ }^{[33]}$. In his experiment, maximal larval total length, individual larval dry weight and SGR were achieved with the treatment which contained $3.97 \%$ n-3 HUFA on a dry weight basis of diet, SGR in this treatment is $21.5 \pm 1.1$, but the larval growth performance declined significantly when the amount of n-3 HUFA was $6.23 \%$ on a dry weight basis of diet, SGR in the treatment was 18.7 \pm 1.4 . Study of Dentex dentex indicated the increasing oxidation of n-3 HUFA in larvae with increasing levels of dietary n-3 HUFA if the amount of n-3 HUFA exceeded the optimal level, and would have a poor performance ${ }^{[33]}$.

In the present experiment, whole body and liver compositions were not to be related to dietary lipid source, but lipid content in muscle varied with lipid source. For example in dorsal muscle, fish oil diet groups had the higher crude lipid content than maize oil diet groups, the result in our experiment is similar with red drum study ${ }^{[13]}$. Previous research with red drum has indicated that certain diet formulations promote excessive lipid deposition in the peritoneal cavity and muscle, which may be indicative of inefficient utilization of dietary components ${ }^{[13]}$. Though total lipid in muscle was significantly affected by dietary lipid, the effect did not seem to detrimentally affect performance, feed efficiency or fatty acid composition of grouper in the present study, fish with high muscle lipid usually experience the greatest weight gain and feed efficiency. Previous research indicated that accumulation of lipid in liver has been identified as a fatty acid deficiency sign in some fish species $[34,35]$, but in our present experiment, there were no significant difference in liver lipid between the two diet groups, which indicated that the maize oil diet satisfied grouper postlarvae requirement for fatty acids. There was an increased level of carcass tissue lipid of $P$. monodon fed a diet containing cod liver oil ${ }^{[36]}$. It was also found that only n-3 HUFA significantly increased the total lipid content of shrimp tissue, but the n-6 HUFA did not significant affect the total lipid content of shrimp tissue ${ }^{[37]}$. In our present study, the fish oil diet had more n-3 HUFA than the maize oil diet and the n-6 HUFA level was the same, this agrees with the conclusion of L. vannamei study ${ }^{[37]}$. 
Am. J. Agri. \& Bio. Sci., 2 (2): 81-87, 2007

Table 4: Selected fatty acid contents (\% of total fatty acids) of the experimental diets and dorsal muscle. n.d.: non-detected. tr.: traces.

\begin{tabular}{lllll}
\hline Fatty acids & $\begin{array}{l}\text { Maize oil } \\
\text { diet }\end{array}$ & $\begin{array}{l}\text { Fish oil } \\
\text { diet }\end{array}$ & $\begin{array}{l}\text { Maize oil } \\
\text { muscle }\end{array}$ & $\begin{array}{l}\text { Fish oil } \\
\text { muscle }\end{array}$ \\
\hline $16: 0$ & $6.63 \pm 0.12^{\mathrm{a}}$ & $5.51 \pm 0.06^{\mathrm{b}}$ & $12.39 \pm 0.62$ & $11.04 \pm 0.57$ \\
$18: 0$ & $4.22 \pm 0.04^{\mathrm{b}}$ & $5.03 \pm 0.06^{\mathrm{a}}$ & $5.22 \pm 0.14$ & $5.58 \pm 0.16$ \\
$22: 0$ & tr. & tr. & $0.50 \pm 0.08$ & $0.57 \pm 0.11$ \\
$16: 1 \mathrm{n}-7$ & $0.08 \pm 0.01^{\mathrm{b}}$ & $0.64 \pm 0.01^{\mathrm{a}}$ & $1.37 \pm 0.25$ & $1.69 \pm 0.13$ \\
$18: 1 \mathrm{n}-9$ & $46.43 \pm 0.54^{\mathrm{a}}$ & $25.93 \pm 0.62^{\mathrm{b}}$ & $27.55 \pm 0.55^{\mathrm{a}}$ & $21.26 \pm 0.72^{\mathrm{b}}$ \\
$22: 1 \mathrm{n}-11$ & $0.53 \pm 0.03^{\mathrm{b}}$ & $1.41 \pm 0.09^{\mathrm{a}}$ & $2.45 \pm 0.17^{\mathrm{b}}$ & $3.50 \pm 0.16^{\mathrm{a}}$ \\
$18: 3 \mathrm{n}-3$ & $0.08 \pm 0.02^{\mathrm{b}}$ & $0.26 \pm 0.02^{\mathrm{a}}$ & $0.12 \pm 0.02^{\mathrm{b}}$ & $0.58 \pm 0.06^{\mathrm{a}}$ \\
$20: 5 \mathrm{n}-3$ & $3.53 \pm 0.18^{\mathrm{b}}$ & $7.07 \pm 0.23^{\mathrm{a}}$ & $3.19 \pm 0.08^{\mathrm{b}}$ & $4.03 \pm 0.29^{\mathrm{a}}$ \\
$22: 6 \mathrm{n}-3$ & $13.37 \pm 0.48^{\mathrm{b}}$ & $26.80 \pm 0.29^{\mathrm{a}}$ & $19.09 \pm 0.95^{\mathrm{b}}$ & $23.43 \pm 0.87^{\mathrm{a}}$ \\
$22: 5 \mathrm{n}-3$ & $1.50 \pm 0.06^{\mathrm{b}}$ & $3.83 \pm 0.09^{\mathrm{a}}$ & $2.93 \pm 0.24^{\mathrm{b}}$ & $3.61 \pm 0.04^{\mathrm{a}}$ \\
$18: 3 \mathrm{n}-6$ & tr. & tr. & $0.12 \pm 0.02^{\mathrm{a}}$ & $0.06 \pm 0.01^{\mathrm{b}}$ \\
$18: 2 \mathrm{n}-6$ & $20.00 \pm 0.40^{\mathrm{a}}$ & $11.30 \pm 0.55^{\mathrm{b}}$ & $17.10 \pm 0.96^{\mathrm{a}}$ & $10.45 \pm 0.41^{\mathrm{b}}$ \\
$20: 4 \mathrm{n}-6$ & $0.67 \pm 0.03^{\mathrm{b}}$ & $0.8 \pm 0.05^{\mathrm{a}}$ & $0.78 \pm 0.02^{\mathrm{b}}$ & $0.96 \pm 0.05^{\mathrm{a}}$ \\
$20: 2 \mathrm{n}-6$ & $0.70 \pm 0.02$ & $0.73 \pm 0.03$ & $1.42 \pm 0.30$ & $1.34 \pm 0.28$ \\
$22: 5 \mathrm{n}-6$ & n.d. & tr. & $0.63 \pm 0.06^{\mathrm{b}}$ & $0.88 \pm 0.03^{\mathrm{a}}$ \\
Saturated & $10.85 \pm 0.09$ & $12.04 \pm 0.12$ & $18.11 \pm 0.56$ & $17.19 \pm 0.78$ \\
Monoenoic & $47.04 \pm 0.54^{\mathrm{a}}$ & $27.98 \pm 0.70^{\mathrm{b}}$ & $31.37 \pm 0.64^{\mathrm{a}}$ & $26.45 \pm 0.44^{\mathrm{b}}$ \\
n-3 HUFA & $17.83 \pm 0.37^{\mathrm{b}}$ & $37.70 \pm 1.00^{\mathrm{a}}$ & $25.22 \pm 1.02^{\mathrm{b}}$ & $31.07 \pm 1.17^{\mathrm{a}}$ \\
n-6 HUFA & $1.37 \pm 0.03$ & $1.53 \pm 0.03$ & $2.83 \pm 0.34$ & $3.18 \pm 0.32$ \\
\hline D & & & & \\
\hline
\end{tabular}

Data represent mean \pm S.E.M. $(\mathrm{n}=3)$.

Values in the same row with different letters are significantly different $(P<0.05)$.

Generally speaking, the fish body fatty acid composition can reflect the fatty acid composition of the diet ${ }^{[38]}$. In the present experiment, the condition of the gross saturated and monounsaturated fatty acids in muscles just the same as the diets, saturated fatty acids had no difference and monounsaturated fatty acids had

significant difference $(18.11 \pm 0.56,17.19 \pm 0.78$ and $31.37 \pm 0.64 \mathrm{a}, \quad 26.45 \pm 0.44 \mathrm{~b}$ respectively). The monounsaturated fatty acids are more from newly synthesized, only a few from the diet ${ }^{[39]}$. When the content of HUFA in the diet is beyond the requirement, monounsaturated fatty acids could be replaced by

redundant HUFA ${ }^{[39]}$. It was considered that the diet HUFA could restrain the monounsaturated fatty acids synthesized ferment, which could lead to the reduction of these fatty acids amounts in fish tissues ${ }^{[40]}$. In the present study, the fish oil diet group had significantly lower monounsaturated fatty acids in dorsal muscle compared with the maize oil diet group $(p<0.05)$. It indicated the fish oil diet had excessive HUFA again.

\section{CONCLUSION}

In conclusion, postlarval grouper were able to efficiently utilize maize oil as the dietary lipid source, once their requirement for EFA is met by a source rich in the long-chain (n-3) HUFA. Total lipid in muscle was significantly affected by dietary lipid, but this effect did not seem to detrimentally affect performance or fatty acid composition of grouper in the present study.

\section{ACKNOWLEDGMENTS}

The authors gratefully acknowledge J.M. Cao for excellent technical assistance in the pretreatment of lipids, and C.Z. Zhang for his assistance with preparation of the diets, and co-workers for the help in sampling. Special thanks were given to teacher W.H. Zheng for helping to analyze fatty acid composition. This work was funded by Key Technologies R\&D Program during the 10th five-year plan, China (grant no. 2001DA505D/06).

\section{REFERENCES}

1. Watanabe, T., V. Kiron., 1995. Red sea bream (Pagrus major). In: Bromage, N.R., Robert, R.J. (Eds.), Broodstock management and egg and larval quality. Blackwell, Great Britain, pp: 398-413.

2. Watanabe, T., 1982. Lipid nutrition in fish. Comp. Biochem. Physiol. 73 B: 3-15.

3. Sargent, J.R., McEvoy, L.A., Estevez, A., Bell, J.G., Bell, M.V., Henderson, R.J., Tocher, D.R., 1999b. Lipid nutrition of marine fish during early development: current status and future directions. Aquaculture 179: 217-229. 
4. Sargent, J.R., Bell, J.G., Bell, M.V., Henderson, R.J., Tocher, D.R., 1993. The metabolism of phospholipids and polyunsaturated fatty acids in fish. In: Lahlou, B., Vitello, P. (Eds.), Aquaculture: Fundamental and Applied Research, Coastal and Estuarine studies 43. American Geophysical Union, Washington DC, USA, pp: 103-124.

5. Ramos, J., Thrush, M., Navas, J.M., Zanuy, S., Carrillo, M., Bromage, N., 1993. Effecto del enriqucimiento lipidico de dietas artificiales sobre el crecimiento, fecundidad y calidad de puesta de la lubina. Actas del IV Congreso Nacional de Aquiculture, 13-18.

6. Sargent, J.R., Tacon, A.G.J., 1999. Development of farmed fish: a nutritionally necessary alternative to meat. Proc. Nutr. Soc. 58: 377.

7. Tacon, A.G.J., 1996. Lipid nutritional pathology in farmed fish. Arch. Anim. Nutr., 49: 33-39.

8. Halver, J.E., Hardy, R.W., 2002. Fish Nutrition (Third Edition). New York: Academic Press

9. Barlow, S., 2000. Fish meal and fish oil: Sustainable feed ingredients for aquafeeds. Global Aquacul. Advocate 4: 85-88.

10. Sargent, J.R., Tocher, D.R., Bell, J. G., 2002. The lipid. In: Fish nutrition (Halver, J.E. eds). Elsevier science publishers. 182-246.

11. McGogan, B.B., Gatlin, D.M., 1999. Dietary manipulations affecting growth and nitrogenous waste production of red drum, Sciaenops ocellatus. I. Effect of dietary protein and energy levels. Aquaculture 178: 333-348.

12. Greene, D.H.S., Selivonchick, D.P., 1990. Effects of dietary vegetable, animal and marine lipids on muscle lipid and hematology of rainbow trout (Oncorhynchus mykiss). Aquaculture 89: 165-182.

13. Craig, S.R., Gatlin, D.M., 1995. Coconut oil and beef tallow, but not tricaprylin, can replace menhaden oil in the diet of red drum (Sciaenops ocellatus) without adversely affecting growth or fatty acid composition. J. Nutr. 125: 3041-3048.

14. Guillou, A., Soucy, P., Khalil, M., Abambounou, L., 1995. Effects of dietary vegetable and marine lipid on growth, muscle fatty acid composition and organoleptic quality of flesh of brook charr (Salvelinus fontinalis). Aquaculture 136: 351-362.

15. Gunasekera, R.M., Leelarasamee, K., De Silva, S.S., 2002. Lipid and fatty acid digestibility of three oil types in the Australian shortfin eel, Anguilla australis. Aquaculture 203: 335-347.
16. Hardy, R.W., Scott, T.M., Harrell, L.W., 1987. Replacement of herring oil with menhaden oil, soybean oil, or tallow in the diets of Atlantic salmon raised in marine net-pens. Aquaculture 65: 267-277.

17. Steffens, W., 1997. Effects of variation in essential fatty acids in fish feeds on nutritive value of freshwater fish for humans. Aquaculture 151: 97119.

18. Sargent, J., Bell, G., McEvoy, L.A., Tocher, D., Estevez, A., 1999a. Recent developments in the essential fatty acid nutrition of fish. Aquaculture 177: 191-199.

19. Ye, C.X., Liu, Y.J., Tian, L.X., Mai, K.S., Du, Z.Y., Yang, H.J., Niu, J., 2006. Effect of dietary calcium and phosphorus on growth, feed efficiency, mineral content and body composition of juvenile grouper, Epinephelus coioides. Aquaculture, 255: 263-271

20. Luo, Z., Liu, Y.J., Mai, K.S., Tian, L.X., Yang, H.J., Tan X.Y., Liu, D.H., 2005. Dietary Lmethionine requirement of juvenile grouper Epinephelus coioides at a constant dietary cystine level. Aquaculture, 249: 409-418.

21. Hseu, J.R., Lu, F.I., Su, H.M., Wang, L.S., Tsai, C.L., Hwang, P.P., 2003. Effect of exogenous tryptophan on cannibalism, survival and growth in juvenile grouper, Epinephelus coioides. Aquaculture, 218: 251-263

22. Millamena, O.M., 2002. Replacement of fish meal by animal by-product meals in a practical diet for grow-out culture of grouper Epinephelus coioides. Aquaculture, 204: 75-84

23. Cahu, C.L., Zambonino Infante, J.L., 2001. Substitution of live food by formulated diets in marine fish larvae. Aquaculture 200: 161-180.

24. Garling, D.L., Wilson, R.P., 1976. Optimum dietary protein to energy ratio for channel catfish fingerlings, Ictalurus punctatus. J. Nutr. 106: 13681375.

25. AOAC (Association of Official Analytical Chemists). 1984. Official Methods of Analysis, 14th edn. AOAC. Arlington, VA. 114. pp.

26. Bligh, E.C., Dyer, W.J., 1959. A rapid method of total lipid extraction and purification. Can J Biochem Physiol 37: 911-927.

27. Zheng, W.H., Liu, Y.J., Tian, L.X., 2002 A simple method for fatty acid analysis of fish liver. Chin J Health Lab Tech 2, 159. 
28. Sargent, J.R., Mcevoy, L.A., Bell, J.G., 1997. Requirements, presentation and sources of polyunsaturated fatty acids in marine fish larval feeds. Aquaculture 155: 117-127.

29. Koven W., Barr, Y., Lutzky, S., Ben-Atia, I., Weiss, R., Harel, M., Behrens, P., Tandler, A., 2001. The effect of dietary arachidonic acid $(20: 4 n-6)$ on growth, survival and resistance to handling stress in gilthead sea bream, Sparus aurata, larvae. Aquaculture 193: 107-122.

30. Izquierdo, M.S., Watanabe, T., Takeuchi, T., Arakawa, T., Kitajima, C., 1989. Requirement of larval seabream Pagrus major for essential fatty acids. Nippan Suisan Gakkaishi 55: 859-867.

31. Watanabe, T., V. Kiron., 1994. Prospects in larval fish dietetics. Aquaculture 124: 223-251.

32. Zambonino Infante, J.L., Cahu, C.L., 1999. High dietary lipid levels enhance digestive tract maturation and improve Dicentrarchus labrax larval development. J. Nutr. 129: 1195-1200.

33. Mourente, G., Tocher, D.R., Diaz-Salvago, E., Grau, A., Pastor, E., 1999. Study of the $n-3$ highly unsaturated fatty acids requirement and antioxidant status of Dentex dentex larvae at the Artemia feeding stage. Aquaculture 179: 291-307.

34. Bautista, M.N., De la Cruz, M.C., 1988. Linoleic (n-6) and linolenic (n-3) acids in the diet of fingerling milkfish (Chanos chanos Forsskal). Aquaculture, 71: 347-358.

35. Watanabe, T., Thongrod, S., Takeuchi, T., Satoh, S., Kubota, S.S., Fujimaki, Y., Cho, C.Y., 1989. Effect of dietary (n-6) and (n-3) fatty acids on growth, fatty acid composition and histological changes of white fish Coregonus iavaretus maraena. Bull. Jpn. Soc. Sci. Fish. 55: 1989-1995.
36. Catacutan, M.R., 1991. Growth and fatty acid composition of Penaeus monodon juveniles fed various lipids. Bamidgeh 43: 47-56.

37. González-Félix, M.L., Lawrence, A.L., Gatlin, D.M., Perez-Velazquez, M., 2003. Nutritional evaluation of fatty acids for the open thelycum shrimp, Litopenaeus vannamei: I. Effect of dietary linoleic and linolenic acids at different concentrations and ratios on juveniles shrimp growth, survival, and fatty acid composition. Aquacul Nutr 9: 105-113.

38. Stowell, S.L., Gatlin, D.M., 1992. Effect of dietary pantethine and Lipid levels on growth and body composition of Channel Catfish, Ictalurus punctatus. Aquaculture 108: 177-188.

39. Lands, W.E.M., Morris, A., Libelt, B., 1990. Quantitative effects of dietary polyunsaturated fats on the composition of fatty acids in rat tissues. Lipids 20: 505-516.

40. Brenner, R.R., Garda, H., Gomez Dumm, I.N.T., Pezzano. H., 1981. Early effects of EFA deficiency on the structure and enzymatic activity of rat liver microsomes. In: Essential Fatty Acid Prostaglandins, Progress in Lipid Research. pp: 315-321 (Holman, R.T., editor). Pergamon Press, Oxford. 